UDC 347.725

DOI https://doi.org/10.32849/2663-5313/2021.11.03

\title{
Liliana Sishchuk,
}

PhD in Law, Associate Professor, Head of the Laboratory of Corporate Law Issues, Academician F. G. Burchak Scientific and Research Institute of Private Law and Entrepreneurship of National Academy of Sciences of Ukraine, 23-a, Raiezskoho street, Kyiv, Ukraine, postal code, 01042, liliana8766@gmail.com ORCID: orcid.org/0000-0002-9722-4347

Scopus-Author ID: 57209970472

Sishchuk, Liliana (2021). Squeeze-out: introduction expediency and fair value challenge. Entrepreneurship, Economy and Law, 11, 17-26, doi https://doi.org/10.32849/2663-5313/2021.11.03

\section{SQUEEZE-OUT: INTRODUCTION EXPEDIENCY AND FAIR VALUE CHALLENGE}

Abstract. The purpose of the article is to substantiate the legality of the squeeze-out procedure given legal opinions about the constitutionality of regulations on the compulsory sale of the shares of minority shareholders and the determination of their fair value.

Research methods. The contribution is based on general scientific and special methods of scientific cognition.

Results. The author analyzed the procedure for exercising squeeze-out, elucidated legal approaches to establishing the constitutionality of provisions covering squeeze-out, outlined legislative approaches to compulsory expropriation. The author also identified a range of problems of a fair value of the stock traded under squeeze-out and offered ways to improve the issue under consideration at the legislative level.

Conclusions. It is argued that the right to compulsory expropriation may be established by the Constitution of Ukraine, the Civil Code of Ukraine, and special laws; the squeeze-out procedure is set under authority and in the manner consolidated in the Law of Ukraine "On Joint-Stock Companies". In addition, the Law contains a guarantee for full compensation for stock value under the relevant terms. The shortcoming of the current legislation is zero guarantees for the protection of the monitory shareholder's rights, whose shares are bought out, which should be specified in the very procedure. It is manifested in the lack of proper control over squeeze-out compliance that, in turn, causes the determination of an unfair market price of shares, which are compulsorily bought out. Therefore, there should be statutory provisions for special control of the court or the National Securities and Stock Market Commission to ensure a transparent squeeze-out and determination of a fair value of the stock.

Key words: squeeze-out, owner of dominant controlling stake, fair price, minority shareholders, public interest, property, ownership.

\section{Introduction}

Over the last few years, the efficiency of a market economy has required addressing a strategic task - to ensure the quality of laws. Permanent legal reforms with frequent alterations in the content of legislative rules and legal procedures in different areas of legal relations without a sound legal doctrine do not do good for society (Tertyshnyk, 2019). In particular, rules of corporate legislation are subject to drastic changes. It is driven by the execution of the state's task - to bring domestic legislation in line with European standards. Each of the implemented changes needs to be discussed and analyzed, and if available gaps or conflicts - a high-quality solution to the existing shortcoming. Therefore, the issue of introducing squeezeout (the procedure of mandatory sale of shares by minority shareholders at the request of majority shareholders) into corporate law was not ignored.

Analyzing the definition of squeeze-out in national law, the legislator has chosen a broader approach - covered by this procedure all joint-stock companies, not only those whose shares are traded on the regulated securities market - than one set out in the standards of EU Directive 2004/25/CC as of April 21, 2004. Instead, a squeeze-out threshold was chosen higher than 90 percent, which is the minimum under the Directive (Shvydka, Lohvynenko, 2021, p. 315).

As it is known, corporate relations are in rapid evolution, hence becoming more complicated. Therefore, they require proper regulation. Juridical facts in the mechanism of legal regulation of corporate relations have all the features of traditional specific differentiation of juridical facts (Zhornokui, 
Slipchenko, 2020, p. 39). According to legal consequences, there are such juridical facts that establish the right; change the right; exercise the right; terminate the right. The availability of the latter leads to the termination of legal relations. Such juridical facts include legal actions related to the squeeze-out procedure.

As the procedure of selling shares through squeeze-out is associated with the compulsory termination of corporate relations of a minority shareholder with the company, the corporate community faces a range of issues concerning the legality of making the relevant amendments to legislation, compliance with the Constitution, imperfection of the proposed mechanism of mandatory alienation of shares (a lack of proper control over the procedure by regulatory authorities; the challenge of determining fair value for shares; a lack of specific ways to protect the rights of minority shareholders, etc.).

The squeeze-out procedure was elucidated in the scientific works by L.M. Bielkin, Yu.M. Zhornokui, A.V. Kostruba, O.V. Kolohoida, L.D. Rudenko, V.M. Tertyshnyk, T.I. Shvydka and other. However, guarantees for the exercise and protection of the rights of minority participants during the compulsory buying out of their shares remain unresolved in terms of legislation.

The purpose of the article is to analyze squeeze-out given legal opinions about the constitutionality of regulations of the compulsory sale of the shares of minority shareholders at the request of the owner of the dominant controlling stake and about legal approaches to determining the fair value of redeemable shares.

The study highlights important scientific and applied issues concerning the legitimacy of the squeeze-out procedure and compliance with the principle of social necessity and justice in case of execution. Keeping in mind the research purpose, the author used methods, which generally allowed establishing the relevant lines: analysis and synthesis, systems analysis, induction and deduction, formal-legal and comparative-legal method, etc. Thus, the structural and functional analysis made it possible to describe the legal procedure for squeeze-out, determine necessary elements of a public irrevocable demand and the method of calculation of the fair price of redeemable shares. Systems analysis and synthesis elucidated the inner nature and impact of the squeeze-out procedure on the rights and interests of minority interests, as well as the lack of adequate guarantees for the exercise and protection of their rights in case of violation.

\section{Legal procedure for exercising} squeeze-out

The Law of Ukraine "On Amendments to Certain Legislative Acts of Ukraine on Increasing the Level of Corporate Governance in Joint-Stock Companies” № 1983-VIII as of March 23, 2017 amended the Law of Ukraine "On Joint-Stock Companies" and updated Arts. 65-1-65-5, which touch upon squeezeout. In particular, Art. 65-2 of the Law envisages the procedure for the mandatory sale of shares by shareholders at the request of a person (persons acting in concert) who is the owner of the dominant controlling interest. Therefore, the owner of the dominant controlling interest is a person (persons acting in concert) who owns 95 and more percent of the ordinary shares of the joint-stock company. Persons acting in concert are natural and/or legal persons who rely on the agreement, which they have concluded and coordinate their actions to achieve a common goal (Verkhovna Rada of Ukraine, 2008).

According to the regulations, the owner of the dominant controlling stake, the applicant of demand, is obliged to notify the National Securities and Stock Market Commission of the acquisition of title within the next working day from the date of acquisition of title to shares. The joint-stock company is also obliged to publish the relevant notice on the JSC website and in the database of the person who carries out the presentation of regulated information on behalf of capital market participants. Since that moment, the owner of the dominant controlling interest acquires the right to appeal to the company and its shareholders, who jointly hold 5 or less percent of ordinary shares, with a public irrevocable demand for buyout. The term for submitting a public irrevocable demand is 90 days after sending the relevant notification to the National Securities and Stock Market Commission, joint-stock company, and capital market (Verkhovna Rada of Ukraine, 2008).

Along with the submission of a public irrevocable claim to the company, it is sent a copy of the agreement concluded between the applicant and the banking institution in which the escrow account is opened. In order to realize the public irrevocable demand, the applicant pays shareholders the share price by transferring the sums of money to the banking institution in which the applicant has opened an escrow account. In this case, the company and minority shareholders are obliged to sell their shares unconditionally. The beneficiaries of such an account are the shareholders who sell the shares or their heirs, successors, and other persons who have the right to receive funds by law. 
The Central Securities Depository (hereinafter - CSD) also posts a public irrevocable demand on its website, imposes restrictions on share transactions within the depository system, and provides depository institutions, the accounts of which hold shares, with a copy of the public irrevocable demand and a certified copy of the escrow agreement. Within three working days from the date of receipt of the relevant notice, the CSD shall compile a list of company shareholders and send it to the company. When the applicant has transferred funds to the escrow account within three working days of the day of receipt of the relevant information, the CSD lifts the restriction on share transactions in the depository system and ensures that depository institutions transfer share rights from the accounts of their owners - minority shareholders - to the applicant's account.

As for the joint-stock company, from receipt of the notice of acquisition of the controlling interest by the owner, the company is obliged to send a copy of the public irrevocable demand and the escrow agreement to each shareholder whose shares are bought out, make a list of persons who sell the shares, indicating the amount to be paid by the applicant in favor of each shareholder, provide the list of such shareholders to the banking institution in which the escrow account is opened. Upon receiving information on the transfer of the specific sums of money from the applicant for the shares of minority shareholders, the company is obliged to notify the CSD within the next business day. The applicant reimburses for JSC expenses related to the execution of the squeeze-out procedure.

The banking institution, which has opened the escrow account, shall, within three years, transfer funds to the banking accounts of shareholders, whose shares are bought out, or pay the fixed funds in cash. In order to receive funds, the shareholders must apply to the banking institution and receive them in non-cash or cash form.

The squeeze-out procedure, introduced through amending the Law of Ukraine "On Joint-Stock Companies", is specified to improve the efficiency of corporate governance in companies. The proposals are one of the directions of European integration processes to bring domestic corporate law in line with EU acquis and the recommendations of the EU Directives.

However, the corporate community met the innovation under consideration with a mixed reception which necessitated the appeal to the Constitutional Court of Ukraine to explain of whether squeeze-out complies with the constitutional provisions of Ukraine. Thus, the subject of the right to a constitutional petition - 47 people's deputies of Ukraine appealed to the Constitutional Court of Ukraine with a request concerning the compliance of the provisions of Art. 65-2 of the Law of Ukraine "On Joint-Stock Companies" with the Constitution of Ukraine (constitutionality).

One of the arguments in favor of such an appeal was the fact that the expropriation of private property objects stipulated by para. 5 of Art. 41 of the Constitution of Ukraine may be applied only as an exception for the reasons of social necessity, on the grounds of and in the order established by the law, and on terms of advance and complete compensation of their value (Verkhovna Rada of Ukraine, 1996). In this regard, the question came up: can squeeze-out be considered a reasonable ground for the expropriation of shares, which, taking into account the provisions of para. 5 of Art. 41 of the Constitution of Ukraine, can occur as an exception for reasons of public necessity?

In addition, the constitutional petition refers to Art. 1 of the First Protocol to the Convention for the Protection of Human Rights and Fundamental Freedoms as of 1950, stating that every natural or legal person is entitled to the peaceful enjoyment of his possessions. No one shall be deprived of his possessions except in the public interest and subject to the conditions provided for by law and by the general principles of international law (Council of Europe, 1952).

Given the above, the subjects of the right to a constitutional petition noted that the expropriation of shareholders' shares through squeeze-out is permissible in the public interest for the legitimate social purpose with observance of the principle of justice and balance of interests without putting a heavy burden on the dispossessed party. However, according to the subjects, the minority shareholder is a weak party in economic terms of corporate relations. Squeeze-out leads to mandatory, independent of the will of the minority shareholder, termination of his rights. The interest of the majority shareholder in reducing the administrative costs of holding shareholders' meetings, minimizing the risks of corporate blackmail on the part of minority shareholders, depriving the company of "dormant shareholders" is not the public interest, but the violation of the right to private ownership of one person in favor of another (Constitutional Court of Ukraine, 2019a).

However, having considered the constitutional petition, the Grand Chamber of the Constitutional Court of Ukraine adopted a ruling as of October 10, 2019, which refused to initiate constitutional proceedings for 
lack of valid grounds (Constitutional Court of Ukraine, 2019b).

If one directly turns to the analysis of current legislation, it is worth mentioning the following. According to Art. 8 of the Constitution of Ukraine, the rule of law is recognized and operates in Ukraine. The Constitution of Ukraine has the highest legal force. Laws and other regulations are adopted by relying on the Constitution of Ukraine and shall comply with it. At the same time, according to Art. 1 of the Civil Code of Ukraine, civil laws govern personal non-property and property relations (civil relations) based on legal equality, free will, and property independence of their participants. Pursuant to Art. 4 of the Civil Code of Ukraine, the Constitution of Ukraine is at the core of the civil legislation of Ukraine. The Civil Code of Ukraine is the principal act of the civil legislation of Ukraine. Other laws of Ukraine, which are adopted in line with the Constitution of Ukraine and the Code Civil, are civil acts as well (Verkhovna Rada of Ukraine, 2003). The above shows that property relations that arise, change, or are terminated from the right to own property are regulated by the Civil Code of Ukraine and special laws adopted on the ground of the Constitution of Ukraine.

Accordingtopara.2,Article3oftheCivilCode of Ukraine, the general principles of civil laws comprise the inadmissibility of expropriation except as provided in the Constitution of Ukraine and the law. Moreover, according to para. 1 of Art. 12 and para. 1 of Art. 13 of the Civil Code of Ukraine, a person shall exercise his civil rights freely, at his own discretion. A person shall exercise his civil rights within limits specified by the agreement or civil law acts (Verkhovna Rada of Ukraine, 2003). Thus, a person exercises his rights freely, at his own discretion, except for the grounds established by law.

Pursuant to Art. 41 of the Constitution of Ukraine, everyone shall have the right to own, use, or dispose of his property and the results of his intellectual or creative activities. No one shall be unlawfully deprived of the right to ownership. The right to private property shall be inviolable (Verkhovna Rada of Ukraine, 1996). These provisions are reflected in the Civil Code of Ukraine. According to Art. 316, para. 1 of Art. 319 of the Code, ownership right shall be the right of an individual to an object (property) that he/she enjoys in compliance with the effective legislation on his/her own will irrespective of the will of the third parties. The owner owns, uses, disposes of his property at his own discretion. According to paras. 1, 2 of Art. 321 of the Civil Code of Ukraine, the right of ownership is inviolable No one can be illegally deprived of this right or restricted in its exercise. The person may be deprived of the ownership right or restricted in their exercise only in cases and in the manner prescribed by the law (Verkhovna Rada of Ukraine, 2003).

By relying on the above legislative provisions, the author concludes the following: 1) the owner freely, at his own discretion, owns, uses, and disposes of his property; 2) the owner exercises the right of ownership within limits set by the law; 3) the owner may be restricted in the right of ownership or deprived of the right of ownership only under the law; 4) the property owner has the right to reimbursement for the value of property in case of restricting his right to property or forced deprivation of property.

Given that the right to expropriation can be determined by the Constitution of Ukraine, the Civil Code of Ukraine and special laws, the squeeze-out procedure is defined on the ground of and in the manner prescribed by the Law of Ukraine "On Joint-Stock Companies". The Law specifies the grounds for applying squeeze-out, the procedure for its implementation and the guarantee for full reimbursement of the stock value on the terms set by the law.

In addition, keeping in mind Art. 1 of the First Protocol to the Convention for the Protection of Human Rights and Fundamental Freedoms, the legal realm concludes that the preceding provisions shall not, however, in any way impair the right of a State to enforce such laws as it deems necessary to control the use of property in accordance with the general interest or to secure the payment of taxes or other contributions or penalties.

Regarding the application of the squeezeout procedure for reasons of public necessity, it is worth noting the following. In 2017, Ukraine implemented the requirements of Directive 2004/25/CC of the European Parliament and of the Council of April 21, 2004 on takeover bids making general squeeze-out recommendations in the European Union. In particular, Arts. 15, 16 provide for the right of mandatory sale (squeeze-out) at the fair price of shares of minority shareholders if the person owns or acquires following acceptance of the bid of at least $90 \%$ of the voting rights in the offeree company. Member States may set a higher threshold that may not, however, be higher than $95 \%$ of the capital carrying voting rights. According to domestic law, the squeeze-out procedure provides for the right of the person (persons acting in concert), who became the owner of 95 or more percent of shares, to conduct a mandatory buyout from minority 
shareholders (European Union, 2004). Thus, the interest threshold has been raised - it allows the owner of the dominant controlling to exercise squeeze-out under domestic law meeting European standards on the threshold of voting rights (the stock of shares).

It should be noted that similar arguments are found in the Judgment of the Grand Chamber of the Supreme Court as of November 24, 2020. It states that Partnership and co-operation agreement between the European communities and their member states and Ukraine was concluded on June 14, 1994. The agreement provided for the approximation of the current and prospective legislation of Ukraine with the legislation of the Community. The Association Agreement between the European Union and the European Atomic Energy Community and their Member States, of the one part, and Ukraine, of the other part, was signed on March 21, 2014 and ratified on September 16, 2014. The Agreement is an integral part of Ukrainian law. Annex XXXIV to Chapter 13 of the Agreement stipulates that Ukraine undertakes to gradually approximate its legislation to EU acquis in terms of the establishment and operation of companies, corporate governance, accounting and auditing within time limits set by the Annex. The annex also contains the Directive on takeover bids (Supreme Court, 2020).

Therefore, public interests in the sustainable operation and development of joint-stock companies have contributed to the state's introduction of the relevant statutory regulation that ensures workplaces and settled taxes in the state, advancement of the investment attractiveness of joint-stock companies, reduction of corporate conflicts, raiding, etc. This requires an appropriate level of corporate governance and minimization of related costs necessary, in particular, to maintain the infrastructure associated with the convening of general company meetings or the exercise of shareholders' other rights and powers (Supreme Court, 2020). The author believes that the above arguments are fair enough and confirm the legality of the squeezeout procedure as defined by the Law of Ukraine "On Joint-Stock Companies". Therefore, squeeze-out may be in the public interests.

\section{Fair value challenge}

Upon acquisition of the dominant controlling stake, the owner - demand applicant - is obliged to send a notice to the National Securities and Stock Market Commission, the Central Securities Depository directly and/or through the company, post it on the JSC website and the stock exchange. The applicant then formulates a public irrevocable demand, which is sent to shareholders and the company. The public irrevocable demand must contain information about the applicant, the purchase price of shares with an indication that the payment for shares is made exclusively in cash, as well as the procedure for setting price, the banking institution in which the escrow account is opened, the joint-stock company, a depository in which the applicant has opened securities account and his account details, the procedure for implementing demand. The public irrevocable demand shall be signed by the applicant.

Although the general procedure and requirements for a public irrevocable demand are set by the law, the application highlights the problem of determining the fair price of the mandatory share sale. Para. 5 of Art. 65-2 of the Law of Ukraine "On JointStock Companies" states that a price is set as the highest of the following: 1) the highest share price under which the applicant, his affiliates, or third parties acting in concert with him bought company stock in 12 months preceding the acquisition date of the dominant controlling interest, including the acquisition date; 2) the highest price under which the mentioned persons indirectly acquired ownership of company stock during 12 months preceding the date of acquisition of the dominant controlling stake, including the date of acquisition, provided that the value of shares owned directly or indirectly by the legal entity is not less than $90 \%$ of total assets following the latest annual financial statements; 3 ) the market value of the company stock set as of the last working day preceding the day when the applicant acquires the controlling company stock (Verkhovna Rada of Ukraine, 2008).

In a joint stock company, the market value of shares is determined under the requirements of para. 2 of Art. 43 of the Law of Ukraine "On Joint-Stock Companies". Thus, the market value of shares, which are not traded on organized capital markets, is determined in accordance with the legislation on the appraisal of property, property rights and professional appraisal activity, and the market value of shares traded on organized capital markets - as the average rate ensuing from regular securities trading on the relevant organized capital market and calculated by the market operator for the last three months of their circulation preceding the day when the market value of securities is determined. If the above procedure does not facilitate determining the market value of shares traded on organized capital markets, it is determined following the legislation on the appraisal of property, 
property rights and professional appraisal activities (Verkhovna Rada of Ukraine, 2008). The decision of the National Commission on Securities and Stock Market "On Determining the Market Value of Securities" first enshrined the proposed options for determining the market value of shares (National Securities and Stock Market Commission, 2016)

Therefore, to set the fair price of a block of shares in the squeeze-out procedure, it is necessary to establish the market value of the company stock. This requires calculations to establish the highest price resulting from the value of a block of shares grounded on the ratio of the value of shares determined by relying on para. 5 of Art. 65-2 of the Law of Ukraine "On Joint Stock Companies" given para. 2 of Art. 8 of the same Law. In other words, the statutory order for determining the purchase price of shares for the relevant procedure envisages choosing the highest rate of the three options set in these rules. The highest rate is the purchase price of shares. At the same time, since share transactions are not carried out on a competitive basis in the domestic organized capital market stock, the more popular approach to determining the fair price of shares in the squeeze-out procedure involves referring to the legislation on the appraisal of property, property rights and professional appraisal activity.

Art. $65-5$ of Ukraine "On Joint-Stock Companies" states that the charter of a private joint stock company in case of its creation as well as the decision of the general meeting of JSC shareholders to amend the company's charter adopted by more than $95 \%$ of shareholders may fix that the requirements of Arts. 65-2 and 65-3 of the Law do not apply to the company or apply with exceptions or peculiarities to be determined by the company's charter (Verkhovna Rada of Ukraine, 2008). As the shares of a private joint stock company are not alienated on organized capital markets, it is obvious that the fair price for shares in the squeeze-out procedure is determined in accordance with the legislation on the appraisal of property, property rights and professional appraisal activity.

With regard to the above provision, it is expressed the opinion that entitling a joint-stock company to independently decide on the terms and conditions of application of the law, in particular, on guarantees of minority rights, can be considered a violation of the principle of equal protection of all subjects of property rights (Shvydka, Lohvynenko, 2021, p. 315). The author believes this comment is reasonable because the squeeze-out procedure determines the price in a public irrevocable demand, which is submitted for obligatory acceptance by a minority shareholder; in the context of buying out, there is no freedom to determine price or recalculate it by a minority shareholder. In addition, the analysis of laws shows that the National Securities and Stock Market Commission or other external supervisory authorities are not involved in the procedure of mandatory sale of shares by a minority shareholder and thus, the shareholder can protect his rights exclusively in court and after the actual conclusion and execution of the sale contract under the squeeze-out procedure.

Therefore, in the above-mentioned constitutional petition, the legal subjects, who appealed to the Constitutional Court of Ukraine, state that the laws of Ukraine do not specify specific requirements for appraisers and the mechanism (way and method) of appraising the market value of shares. This causes inconsistency in the assessment of the market value of shares with the fair market value of the shares in order to apply the squeeze-out procedure. The introduction of the Directive 2004/25/CC into domestic legislation should be preceded by the development and approval of the Regulation on the valuation of the market value of shares for the implementation of share buyback procedures defined by the Law of Ukraine "On Joint-Stock Companies". These Regulations should stipulate requirements for property appraisers (for example, companies, the income of which exceeds UAH 500 million for the previous reporting year, must be appraised by the Big Four - PricewaterhouseCoopers, Deloitte Touche Tohmatsu, Ernst \& Young, KPMG), assessment methods and techniques, the responsibility of assessors for providing unreliable information (Constitutional Court of Ukraine, 2019a).

If one refers to the analysis of the Directive $2004 / 25 /$ CC as of April 21, 2004, the following should be noted in this regard. Para. 4 of Art. 5 states that the highest price paid for the same securities by the offeror, or by persons acting in concert with him/her, over a period, to be determined by Member States, of not less than six months and not more than 12 before the bid shall be regarded as the equitable price. The Directive also provides for the possibility of raising or lowering the maximum price by the supervisory authorities of Member States that requires determining a list of probable circumstances that will facilitate this process. For example, if the highest price was set by agreement between the purchaser and a seller, if the market prices of the securities in question have been manipulated, if market prices in general or certain market prices in particular have been affected by exceptional occurrences, 
or in order to enable a firm in difficulty to be rescued. They may also determine the criteria to be applied in such cases, for example, the average market value over a particular period, the break-up value of the company or other objective criteria generally used in financial analysis. In the form of compensation, the bidder may offer securities, cash or a combination of both. In addition, para. 5 of Art. 15 of the Directive notes that Member States shall ensure that a fair price is guaranteed. That price shall take the same form as the consideration offered in the bid or shall be in cash (European Union, 2004).

International Financial Reporting Standard 13 sets out the criteria for determining fair value, namely: a) defines fair value; b) sets out in a single IFRS a framework for measuring fair value; c) requires disclosures about fair value measurements. Fair value is a market-based measurement, not an entity-specific measurement. For some assets and liabilities, observable market transactions or market information might be available. For other assets and liabilities, observable market transactions and market information might not be available. However, the objective of fair value measurement in both cases is the same - to estimate the price at which an orderly transaction to sell the asset or to transfer the liability would take place between market participants at the measurement date under current market conditions (i. e., an exit price at the measurement date from the perspective of a market participant that holds the asset or owes the liability) (International Accounting Standards Board, 2013)

Based on the above provisions, it is worth pointing out that, on the one hand, the current legislation lacks a specific method of valuing company stock redeemable on the capital market or outside it voluntarily or compulsorily. However, on the other hand, the legislator has granted the stock company's supervisory board, which is responsible for the clarity and transparency of the procedure, considerable powers to monitor the determination of a fair price. Moreover, many practicing appraisers note that the legislation on the valuation of property and property rights envisages approaches that should and have to be applied in the valuation of shares. The crucial thing is to choose an acceptable model when choosing a valuation method because the choice of an unsuitable valuation model can lead to overestimation or underestimation of business that, in particular, is conditioned by the company's performance peculiarities, negative market conditions, and incorrect wording of valuation goal. There are three widely used valuation methods: the market approach, the cost approach, and the revenue approach.

Arts. 12, 13 of the Law of Ukraine "On the Appraisal of Property, Property Rights and Professional Appraisal Activity in Ukraine" stipulate that property valuation findings are elucidated in the property valuation report, which specifies procedures and the used legal framework for property valuation. In addition, it is drawn up an appraisal report, which is a document that contains conclusions on the property value and confirms performed property valuation procedures. A review of the appraisal report (appraisal act) may be conducted at the request of the person using the property appraisal and its findings for decision-making (Verkhovna Rada of Ukraine, 2001).

According to the National Standard № 1 "General principles of the appraisal of property and property rights" № 1440 (sub-paras. 35, $36,37,38,40)$, property appraisal is carried out using methodological approaches, valuation methods that are elements of methodological approaches or the outcome of combining several methodological approaches, as well as evaluation procedures. As a rule, an appraiser applies several methodological approaches that best meet the purpose of the appraisal, the type of value if available reliable information sources for its implementation. The following basic methodological approaches are used to appraise property: cost, income, comparative. Particularities of applying the cost (real estate) approach are established for the valuation of objects in the form of integral property complexes and in the form of financial interests, which include shares (Cabinet of Ministers of Ukraine, 2003). The above provisions show that in conducting the valuation of shares, the appraiser must apply the cost approach individually or in combination with other approaches, taking into account market conditions, efficiency of company performance, completeness of initial data on the company's operations and its assets, etc.

As for the challenge of determining the fair price of shares in the squeeze-out procedure, the fact of the matter is that there is a likelihood of unfair practice of the owner of the dominant controlling stake, a lack of influence of the minority shareholder on determining the price of shares upon their alienation without his will and a lack of special control over the determination procedure before depriving the minority shareholder of the right of ownership of shares. Therefore, the Resolution of the Grand Chamber of the Supreme Court as of November 24, 2020 states that in case 
of minority shareholders' appeal of the procedure of forced alienation of their shares under Art. 65-2 of the Law of Ukraine "On JointStock Companies", the court must establish: 1) whether this procedure was conducted in accordance with the law; 2) whether it was carried out for a legitimate purpose, namely, whether the motives of the majority shareholders were in the public interest when implementing this procedure; 3 ) whether the value of share buyback offered to minority shareholders is fair, and whether the criterion of proportionality of interference with the plaintiff's rights is met (Supreme Court, 2020).

The criteria of the expediency of the squeezeout procedure are consistent with the standpoint of the European Court of Human Rights, which developed three criteria for the compatibility of interference with the right of a person to the peaceful enjoyment of possession with the guarantees of Art. 1 of the First Protocol, namely: 1) whether the interference is lawful; 2) whether it pursues a "social", "public" interest; 3) whether such a measure (interference with the right to the peaceful enjoyment of possession) is proportionate to the objectives set. In the case of violation of the right to the peaceful enjoyment of possession by at least one of these criteria, the European Court of Human Rights notes a violation.

The Grand Chamber of the Supreme Court of Ukraine, referring to Protocol № 1 to the Convention for the Protection of Human Rights and Fundamental Freedoms of 1950, also marks that when performing squeeze-out, the price should be both market and fair. The Supreme Court holds that the cost valuation method (as single, or among others), which follows from the legislation on the appraisal of property, property rights and professional appraisal activity in Ukraine, should be used in calculating the fair (market) value of shares in terms of squeeze-out. When applying the cost approach, the fair (market) price of one ordinary share of the company should be determined in the package of $100 \%$ of the authorized capital by the formula: "market value of the company's net assets divided by total ordinary company stock" (Supreme Court, 2021).

Thus, as you can see, the application practice and case law have already developed some criteria and formulas for determining the fair price of shares in the squeeze-out procedure. However, it is emphasized that there is no adequate control over the observance of the legality principle during the squeeze-out procedure.

Thus, in Ukraine, squeeze-out shares are evaluated by an appraiser appointed by the issuer without the obligatory participation of an additional reviewer or a state disinterested arbitrator from the state (regulator or court) That does not mean that any stock valuation ordered by the issuer is a priori unfair, but such a procedure does not sufficiently protect against valuation misuse. Foreign case law shows that each occasion of unfair valuation should be considered within a specific buyout procedure (Ihonin, Shmatov, 2019). Therefore, in order to improve the squeeze-out procedure in the national legislation, it is proposed to amend the powers of the National Securities and Stock Market Commission in the part of reviewing the appraiser's report and acceptance of complaints from minority participants in case of the violation of proportionality and sufficiency criteria (Shvydka, Lokhvynenko, 2021, p. 317). However the question of what minority shareholders should do in the case of a negative review remains open (Bielkin, 2018).

\section{Conclusions}

The Law of Ukraine "On JointStock Companies" consolidates the right to the mandatory buyout at the request of the owner of the dominant controlling stake. The squeeze-out procedure does not contradict the constitutional provisions on the inviolability of property rights, as it is defined on the grounds of and under the procedure established by law. The drawback of the current legislation is the lack of guarantees to protect the rights of the minority shareholder, whose shares are redeemed, which should be envisaged in this procedure that is primarily manifested in the absence of proper control over its observance. Thus, to conduct a transparent squeeze-out and determine the fair price of redeemable shares, it is necessary to introduce statutory provisions on specific control within this procedure on the part of the court or the National Commission on Securities and Stock Market.

\section{References:}

Bielkin, L.M. (2018). Problemy realizatsii protsedury squise-out: suddi poky ne u zakhvati [Problems of implementation of the squise-out procedure: judges are not yet delighted]. Mezhdunarodnyy nauchnyy zhurnal "Internauka". Seriya "Yuridicheskie nauki" - International scientific journal "Internauka". Series "Juridical Sciences", no. 5. Retrieved from: https:// www.inter-nauka.com/uploads/public/15312325157885.pdf [in Ukrainian].

Cabinet of Ministers of Ukraine (2003). Postanova Kabinetu Ministriv Ukrainy "Pro zatverdzhennia Natsionalnoho standartu № 1 "Zahalni zasady otsinky maina i mainovykh prav" 
vid 10 veresnia 2003 r. № 1440 [Resolution of the Cabinet of Ministers of Ukraine "On approval of the National Standard № 1 "General principles of property valuation and property rights" from September 10, 2003 № 1440]. Retrieved from: https://zakon.rada.gov.ua/laws/show/1440-2003$\% \mathrm{D} 0 \% \mathrm{BF} \# \mathrm{Text}$ [in Ukrainian].

Constitutional Court of Ukraine (2019a). Konstytutsiine podannia 47 narodnykh deputativ Ukrainy [Constitutional submission of 47 people's deputies of Ukraine]. Retrieved from: https://ccu.gov.ua/novyna/do-konstytuciynogo-sudu-ukrayiny-nadiyshlo-konstytuciynepodannya-47-narodnyh-deputativ-7 [in Ukrainian].

Constitutional Court of Ukraine (2019b). Ukhvala Velykoi Palaty Konstytutsiinoho Sudu Ukrainy № 45-y/2019 vid 10 zhovtnia 2019 r. (sprava № 1-195/2019(4549/19)) [Decision of the Grand Chamber of the Constitutional Court of Ukraine № 45-y/2019 of October 10, 2019 (case № 1-195/2019(4549/19))]. Retrieved from: https://zakon.rada.gov.ua/laws/show/ v045u710-19\#Text [in Ukrainian].

Council of Europe (1952). Pershyi protokol do Konventsii pro zakhyst prav i osnovnykh svobod liudyny [The first protocol to the Convention for the Protection of Human Rights and Fundamental Freedoms]. Retrieved from: http://consultant.parus.ua/?doc=00DQNE623D [in Ukrainian].

European Union (2004). Dyrektyva № 2004/25/CC Yevropeiskoho parlamentu ta Rady vid 21 kvitnia 2004 roku pro propozytsii pohlynannia [Directive № 2004/25/CC of the European Parliament and of the Council of April 2162004 on takeover proposals]. Retrieved from: https://www.pard.ua/download.php?downloadid=1086 [in Ukrainian].

Ihonin, V., Shmatov, A. (2019). Tsina skviz-autu: v poshukakh spravedlyvosti [The price of a quiz-out: in search of justice]. Yurydychna hazeta online - Legal newspaper online, February 18. Retrieved from: https://yur-gazeta.com/publications/practice/korporativnepravo-ma/cina-skvizautu-v-poshukah-spravedlivosti.html [in Ukrainian].

International Accounting Standards Board (2013). Mizhnarodnyi standart finansovoi zvitnosti 13 “Otsinka spravedlyvoi vartosti” vid 1 sichnia 2013 r. № 929068 [International Financial Reporting Standard 13 "Fair Value Measurement” as of January 1, 2013 № 929_068]. Retrieved from: https://zakon.rada.gov.ua/laws/show/929_068\#Text [in Ukrainian].

National Securities and Stock Market Commission (2016). Rishennia Natsionalnoi komisii z tsinnykh paperiv ta fondovoho rynku "Pro vyznachennia rynkovoi vartosti tsinnykh paperiv" vid 29 bereznia 2016 r. № 360 [Decision of the National Commission on Securities and Stock Market "On Determining the Market Value of Securities" of March 29, 2016 № 360]. Retrieved from: https:// www.nssmc.gov.ua/documents/pro-viznatchennya-rinkovo-vartost-tsnnih-paperv/ [in Ukrainian].

Shvydka, T.I., Lohvynenko, S.S. (2021). Dotrymannia harantii neporushnosti prava vlasnosti $\mathrm{v}$ mekhanizmi realizatsii protsedury skviz-autu [Guarantees of non-infringement of ownership rights in the mechanism of implementation of the squeeze-out procedure]. Yurydychnyi naukovyi elektronnyi zhurnal - Legal scientific electronic journal, no. 4, pp. 314-317. DOI https:// doi.org/10.32782/2524-0374/2021-4/76 [in Ukrainian].

Supreme Court (2020). Postanova Velykoi Palaty Verkhovnoho Sudu vid 24 lystopada 2020 r. u spravi № 908/137/18 [Resolution of the Grand Chamber of the Supreme Court of 24 November 2020 in the case № 908/137/18]. Retrieved from https://reyestr.court.gov.ua/Review/93336732 [in Ukrainian].

Supreme Court (2021). Postanova Velykoi Palaty Verkhovnoho Sudu vid 17 liutoho 2021 r. u spravi № 905/1926/18 [Resolution of the Grand Chamber of the Supreme Court of 17 February 2021 in the case № 905/1926/18]. Retrieved from: http://iplex.com.ua/doc. php? regnum $=95573646 \&$ red=10000320f3b4b3a37c5c1612a976de2b00eec0\&d=5 [in Ukrainian] .

Tertyshnyk, V.M. (2019). "Squeeze-out" (skviz-aut): yurydychna znakhidka chy pravnychyi ofsaid na rynku kapitaliv ["Squeeze-out": legal discovery or legal for offside on the capital market]. Aktualni problemy vitchyznianoi yurysprudentsii - Actual problems of domestic jurisprudence, no. 1, pp. 164-167 [in Ukrainian].

Verkhovna Rada of Ukraine (1996). Konstytutsiia Ukrainy vid 28 chervnia 1996 r. [Constitution of Ukraine of June 28, 1996]. Retrieved from: https://zakon.rada.gov.ua/laws/ show $/ 254 \%$ D0\%BA/96-\%D0\%B2\%D1\%80\#Text [in Ukrainian].

Verkhovna Rada of Ukraine (2001). Zakon Ukrainy "Pro otsinku maina, mainovykh prav ta profesiinu otsinochnu diialnist v Ukraini” vid 12 lypnia 2001 r. № 2658-III [Law of Ukraine "On Valuation of Property, Property Rights and Professional Valuation Activity in Ukraine" of July 12, 2001 № 2658-III]. Retrieved from: https://zakon.rada.gov.ua/laws/show/2658-14\#n281 [in Ukrainian].

Verkhovna Rada of Ukraine (2003). Tsyvilnyi kodeks Ukrainy vid 16 sichnia 2003 r. № 435-IV [Civil Code of Ukraine of January 16, 2003 № 435-IV]. Retrieved from: https://zakon.rada.gov.ua/ laws/show/435-15\#Text [in Ukrainian]. 
Verkhovna Rada of Ukraine (2008). Zakon Ukrainy "Pro aktsionerni tovarystva" vid 17 veresnia 2008 r. № 514-VI [Law of Ukraine "On Joint Stock Companies" of September 17, 2008 № 514-VI]. Retrieved from: https://zakon.rada.gov.ua/laws/show/514-17\#Text [in Ukrainian].

Zhornokui, Yu.M., Slipchenko, S.O. (2020). Pidstavy vynyknennia, zminy ta prypynennia korporatyvnykh pravovidnosyn [Grounds for the emergence, change and termination of corporate relations]. Visnyk Natsionalnoi akademii pravovykh nauk Ukrainy - Bulletin of the National Academy of Legal Sciences of Ukraine, no. 1, pp. 39-57. DOI: 10.37635/jnalsu.27(1) [in Ukrainian].

\section{Ліліана Сімук,}

кандидат юридичних наук, доцент, завідувач лабораторії проблем корпоративного права, Науково-дослідний інститут приватного права і підприємництва імені академіка Ф. Г. Бурчака Національної академії правових наук України, вулиия Раєвського, 23-а, Київ, Україна, індекс 01042, liliana8766@gmail.com

ORCID: orcid.org/0000-0002-9722-4347

Scopus-Author ID: 57209970472

\section{SQUEEZE-OUT: ДОЦІЛЬНІСТЬ ЗАПРОВАДЖЕННЯ ТА ПРОБЛЕМА СПРАВЕДЛИВОЇ ОЦІНКИ}

Анотація. Метою статmi є обгрунтування законності процедури squeeze-out з урахуванням правових позицій щодо конституційності нормативних положень процедури обов'язкового продажу пакета акцій міноритарних акціонерів та визначення справедливої ціни за акції.

Методи дослідження. Роботу виконано на підставі загальнонаукових та спеціальних методів наукового пізнання.

Результати. Проаналізовано порядок здійснення squeeze-out, розглянуто правові підходи до визначення конституційності положень, що розкривають процедуру squeeze-out, та окреслено законодавчі підходи до примусового позбавлення права власності особи. Також розкрито проблему справедливої оцінки пакета акцій, який викуповується, за процедурою squeeze-out та запропоновано шляхи вдосконалення зазначеного питання на законодавчому рівні.

Висновки. Аргументовано, що право на примусове позбавлення права власності може встановлюватися Конституцією України, Цивільним кодексом України та спеціальними законами. Процедура squeeze-out € такою, що визначається на підставі й у порядку, що закріплені в Законі України «Про акціонерні товариства». Крім того, у цьому ж законі прописано гарантію повного відшкодування вартості акцій на умовах, що ним визначені. Недоліком чинного законодавства є відсутність гарантій захисту прав міноритарного акціонера, акції якого викуповуються, що мають бути передбачені саме в цій процедурі. Це проявляється у відсутності належного контролю за дотриманням squeeze-out, що своєю чергою зумовлює можливість визначення несправедливої ринкової вартості акцій, які продаються, в обов'язковому порядку. Тому для прозорого проведення squeeze-out та визначення справедливої ціни акцій, які викуповуються, на законодавчому рівні варто запровадити положення про спеціальний контроль із боку суду або Національної комісії із цінних паперів та фондового ринку за цією процедурою.

Ключові слова: squeeze-out, власник домінуючого контрольного пакета акцій, справедлива ціна, міноритарні акціонери, суспільний інтерес, майно, право власності.

The article was submitted 15.11.2021

The article was revised 06.12.2021

The article was accepted 27.12.2021 